\title{
Model Pembelajaran Kooperatif Tipe Student Teams Achievement Division (STAD) untuk Meningkatkan Pemahaman Konsep Matematika
}

\author{
Ari Septian ${ }^{1 *}$, Deby Agustina ${ }^{2}$, Destysa Maghfirah ${ }^{3}$ \\ 1,2,3 Universitas Suryakancana \\ *)ariseptian@unsur.ac.id
}

\begin{abstract}
Abstrak
Kurangnya pemahaman siswa terhadap konsep dan kurangnya keterampilan guru dalam menyampaikan materi pelajaran, sehingga siswa bingung bagaimana cara menyelesaikan soal dan untuk apa sebenarnya mereka belajar matematika.Hal ini sering dialami oleh siswa di sekolah dalam proses kegiatan belajar matematika. Tujuan penelitian ini adalah untuk menganalisis peningkatan kemampuan pemahaman konsep matematika, aktivitas belajar siswa dan sikap siswa terhadap pembelajaran dengan menggunakan model pembelajaran kooperatif tipe STAD. Penelitian ini menggunakan Penelitian Tindakan Kelas (PTK). SMA Pasundan 1 melaksanakan dua siklus sesuai dengan kebutuhan penelitian. Subjek penelitian ini yaitu siswa kelas XI MIA 1 di SMA Pasundan 1 Cianjur. Data yang digunakan diperoleh dari hasil tes siklus, hasil obervasi aktivitas, hasil angket skala sikap, dan hasil wawancara. Instrumen yang digunakan adalah tes siklus, lembar observasi, jurnal, skala sikap, dan wawancara. Hasil penelitian ini menunjukkan bahwa hasil tes yang diperoleh siswa mengalami peningkatan sebesar 8,57\%, sehingga dapat disimpulkan bahwa model pembelajaran kooperatif tipe STAD dapat meningkatkan kemampuan pemahaman konsep matematika siswa, perkembangan aktivitas siswa yang sangat baik, dan sikap siswa menunjukkan hasil yang positif pada setiap siklusnya.
\end{abstract}

Kata Kunci: Matematika, Pemahaman Konsep, STAD.

\begin{abstract}
Lack of student understanding of concepts and lack of teacher skills in delivering subject matter, so students are confused about how to solve problems and what they are actually learning mathematics. This is often experienced by students in schools in the process of learning mathematics. The purpose of this study was to analyze the improvement in the ability to understand mathematical concepts, student learning activities and students' attitudes towards learning by using the STAD type cooperative learning model. This research uses Classroom Action Research (CAR). Pasundan 1 High School carries out two cycles in accordance with research needs. The subjects of this study were students of class XI MIA 1 at Pasundan 1 Cianjur High School. The data used were obtained from the results of the cycle test, the results of the activity observation, the results of the attitude scale questionnaire, the results of the interview. The instruments used were cycle tests, observation sheets, journals, attitude scales, and interviews. The results of this study indicate that the test results obtained by students have increased by $8.57 \%$, so it can be concluded that the STAD type cooperative learning model can improve the ability to understand students' mathematical concepts, the development of excellent student activities, and student attitudes show positive results on every cycle.
\end{abstract}

Keywords: Mathematics, Concept Understanding, STAD. 


\section{Pendahuluan}

Pendidikan merupakan media yang memiliki peranan penting untuk membantu manusia dalam mengembangkan potensi dirinya, melalui pendidikan akan terjadi proses pemberdayaan manusia menjadi sumber daya yang berkualitas. Pendidikan juga berfungsi sebagai sarana mencapai semua yang di cita-citakan oleh seseorang dalam kehidupannya.. Penyelenggaraan pendidikan tidak dapat dilepaskan dari tujuan pendidikan yang hendak dicapainya (Depdiknas, 2003).

Matematika tidak bisa lepas dari bentuk-bentuk serta struktur-struktur yang abstrak yang mana kita mencoba mempelajarinya dengan mencari hubungan diantara hal-hal tersebut. Untuk memahami struktur-struktur serta hubungan-hubungannya kita perlu terlebih dahulu memahami konsep-konsep yang ada dalam matematika itu (Depdiknas, 2005).

Pemahaman konsep merupakan kompetensi siswa yang ditunjukkan dalam memahami konsep dalam melakukan prosedur (Algoritma) yang tertata dan tersusun secara sistematis, secara luwes, akurat, efisien, dan tepat. Selain itu kemampuan pemahaman konsep membutuhkan tingkat abstraksi yang tinggi (Dewiatmini, 2010; NCTM, 2014).

Dapat disimpulkan kemampuan pemahaman konsep sangat penting untuk pembelajaran matematika. Siswa yang memiliki tingkat kemampuan pemahaman konsep yang tinggi akan lebih mudah dalam memahami pelajaran matematika di kelas (Maskur et al., 2020). Siswa dikatakan memahami suatu konsep berdasarkan kata-kata sendiri, tidak sekedar menghafal dan dapat membedakan serta mengelompokkan benda-benda (objek) ke dalam contoh dan non contoh. Selain itu ia juga dapat menemukan dan menjelaskan kaitan suatu konsep dengan konsep lainnya yang telah diberikan terlebih dahulu (Jusniani, 2018). Dengan demikian, pemahaman konsep matematika peserta didik harus ditingkatkan karena merupakan salah satu faktor penting dalam pencapaian tujuan pembelajaran dan peningkatan prestasi belajar siswa.

Berdasarkan hasil observasi awal di SMA Pasundan 1 Cianjur yang dilakukan melalui wawancara dengan salah seorang guru matematika di sekolah tersebut, diperoleh informasi bahwa dalam kegiatan belajar mengajar peristiwa yang sering terjadi adalah kurangnya pemahaman siswa terhadap konsep matematika dan kurangnya keterampilan guru dalam menyampaikan materi pembelajaran, sehingga siswa bingung bagaimana cara menyelesaikan soal dan untuk apa sebenarnya mereka belajar matematika. 
Guru sebagai salah satu kunci keberhasilan dalam peningkatan pemahaman konsep matematika siswa, berperan sebagai fasilitator dan bukan sumber utama pembelajaran. Guru berada pada titik sentral untuk mengatur, mengarahkan dan menciptakan suasana belajar mengajar yang mendukung pencapaian tujuan pembelajaran. Peningkatan pemahaman konsep matematika siswa sedikit banyak tergantung pada cara guru menyampaikan pelajaran pada anak didiknya (Inayah, Septian, \& Suwarman, 2020).

Kesulitan belajar matematika akan dapat diselesaikan dengan cara memperbaharui cara mengajar guru kepada siswanya. Beberapa model pembelajaran digunakan di kelas dengan tujuan meningkatkan pemahaman terhadap konsep dalam matematika. Upayaupaya dengan mengganti atau menggunakan model pembelajaran disesuaikan dengan materi atau jenis pelajarannya. Pada penelitian-penelitian sebelumnya, dengan menggunakan model STAD dapat meningkatkan kemampuan pemahaman matematika siswa di sekolah dari berbagai jenjang.

Model pembelajaran ini bertujuan untuk menciptakan proses belajar aktif serta memungkinkan timbulnya sikap ketertarikan siswa untuk mengikuti kegiatan belajar mengajar secara menyeluruh. Memberikan kesempatan pada siswa untuk bertukar pendapat, menanggapi pemikiran siswa yang lain, saling bekerja sama, menggunakan media yang ada, akan dapat mengingat lebih lama mengenai suatu fakta, prosedur, definisi dan teori dalam matematika (Anggriani \& Septian, 2019).

Model pembelajaran kooperatif tipe Student Teams Achievement Division (STAD) diharapkan dapat meningkatkan pemahaman konsep matematika siswa (Zyngier et al., 2013). Model Student Teams Achievement Divisions (STAD) adalah salah satu tipe model pembelajaran kooperatif yang menekankan pada prestasi tim yang diperoleh dari jumlah seluruh skor kemajuan individual setiap anggota tim (Yanuar, Sukmawati, \& Arifin, 2019).

Penelitian ini bertujuan diantaranya: 1) Untuk menganalisis apakah model pembelajaran kooperatif tipe Student Teams Achievement Division (STAD) dapat meningkatkan pemahaman konsep matematika siswa SMA; 2) Untuk menganalisis aktivitas siswa terhadap pembelajaran matematika dengan menggunakan model pembelajaran kooperatif tipe Student Teams Achievement Division (STAD); 3) Untuk menganalisis sikap siswa terhadap pembelajaran matematika dengan menggunakan model pembelajaran kooperatif tipe Student Teams Achievement Division (STAD). 


\section{Metode Penelitian}

Metode yang digunakan adalah Penelitian Tindakan Kelas (PTK). Tindakan yang diberikan adalah penerapan model pembelajaran kooperatif tipe Student Teams Achievement Division (STAD). Sesuai dengan model Kurt Lewin, penelitian dilaksanakan dalam beberapa kegiatan berulang atau siklus, dimana pada setiap siklusnya terdapat empat tahap yaitu perencanaan (planning), tindakan (action), pengamatan (observation), dan refleksi (reflection). Subjek penelitian ini adalah siswa kelas XI MIA 1 tahun ajaran 2014/2015 di SMA Pasundan 1 Cianjur, dengan jumlah 35 orang siswa yang terdiri dari 18 orang siswa laki-laki dan 17 orang siswa perempuan.

Teknik pengumpulan data yang digunakan pada penelitian ini adalah tes siklus, observasi, jurnal, skala sikap, dan wawancara. Data yang diperoleh pada setiap siklus tindakan penelitian dibagi menjadi dua jenis yaitu data kuantitatif dan data kualitatif. Data kuantitatif berupa data yang diperoleh berdasarkan hasil tes tertulis siswa sedangkan data kualitatif berupa tes pemahaman konsep (tertulis), penghargaan prestasi kelompok, lembar observasi aktivitas guru dan siswa, jurnal, skala sikap, dan wawancara.

Data kuantitatif berasal dari hasil tes belajar siswa pada setiap akhir siklus. Analisis data kuantitatif digunakan untuk memberikan gambaran tentang peningkatan pemahaman konsep siswa setelah mengikuti pembelajaran matematika dengan model pembelajaran kooperatif tipe Student Teams Achievement Division (STAD). Untuk menganalisis data kuantitatif dan didapatkan hasil mengenai ketuntasan belajar siswa serta peningkatan hasil belajar siswa maka digunakan rumus Daya Serap Siswa (DSS), Daya Serap Klasikal (DSK) dan nilai rata-rata.

Pada data kualitatif, untuk menganalisis pemahaman konsep data tes tertulis siswa yang berasal dari tes siklus I sampai tes siklus III dianalisis dan dibuat kategori jawaban untuk menentukan tingkat pemahaman konsep siswa. Untuk melihat tingkat pemahaman konsep berdasarkan ciri-ciri jawaban yang dikemukakan siswa terhadap pertanyaan yang diberikan dapat melihat rubrik penskoran tingkat pemahaman konsep menurut Abraham (Wandi, 2013) pada Tabel 1. 
Tabel 1. Tingkat Pemahaman Konsep Siswa Menurut Abraham

\begin{tabular}{|c|l|c|}
\hline Tingkat Pemahaman & \multicolumn{1}{|c|}{ Ciri Jawaban Siswa } & Skor \\
\hline Paham Seluruhnya (P) & $\begin{array}{l}\text { Jawaban benar dan mengandung seluruh konsep } \\
\text { ilmiah. }\end{array}$ & 4 \\
\hline Paham Sebagian (PS) & $\begin{array}{l}\text { Jawaban benar dan mengandung paling sedikit } \\
\text { satu konsep ilmiah serta tidak mengandung } \\
\text { suatu kesalahan konsep. }\end{array}$ & 3 \\
\hline $\begin{array}{c}\text { Miskonsepsi Sebagian } \\
\text { (MS) }\end{array}$ & $\begin{array}{l}\text { Jawaban memberikan sebagian informasi yang } \\
\text { benar tapi juga menunjukkan adanya kesalahan } \\
\text { konsep dalam menjelaskannya. }\end{array}$ & 2 \\
\hline $\begin{array}{c}\text { Miskonsepsi (M) } \\
\text { Jawaban menunjukkan kesalahan pemahaman } \\
\text { yang mendasar tentang konsep yang dipelajari. }\end{array}$ & 1 \\
\hline Tidak Paham (TP) & $\begin{array}{l}\text { Jawaban salah, tidak relevan/jawaban hanya } \\
\text { mengulang pertanyaan, jawaban kosong. }\end{array}$ & 0 \\
\hline
\end{tabular}

Penghargaan prestasi kelompok diberikan setelah dilaksanakannya pembelajaran dengan menggunakan model pembelajaran kooperatif tipe Student Teams Achievement Division (STAD). Setelah guru memberikan soal tes kuis/tes siklus kemudian guru memeriksa hasil kerja setiap siswa dan diberikan nilai dengan angka yang memiliki rentang dari 0 sampai 100. Selanjutnya pemberian penghargaan atas keberhasilan kelompok yang didasari oleh hasil kerja siswa secara individu dapat dilakukan oleh guru dengan terlebih dahulu menghitung perkembangan skor individu, setelah itu dihitung skor kelompok dengan rata-rata skor perkembangan anggota kelompok, yaitu menjumlahkan semua skor perkembangan individu anggota kelompok dan membagi sejumlah anggota kelompok tersebut. Bagi kelompok dengan rata-rata skor tertinggi maka akan mendapatkan hadiah sebagai penghargaan.

Data hasil observasi merupakan data yang didapat dengan cara mengamati setiap kejadian pada saat pembelajaran matematika menggunakan model pembelajaran kooperatif tipe Student Teams Achievement Division (STAD) sedang berlangsung. Berdasarkan pedoman observasi pembelajaran, data hasil observasi akan dianalisis yaitu untuk jawaban "ya" akan diberi skor 1 dan jawaban "tidak" diberi skor 0 . Hasil observasi yang telah dianalisis kemudian dirubah kedalam bentuk persentase selanjutnya dikategorikan sesuai dengan klasifikasi hasil observasi.

Analisis jurnal siswa dilakukan dengan cara mengelompokkan pendapat siswa pada jurnal, ditujukan untuk mengetahui sikap siswa terhadap pembelajaran kooperatif tipe Student Teams Achievement Division (STAD). Pengelompokkan kesan siswa dibagi ke 
dalam dua kategori, yaitu komentar positif dan komentar negatif. Kemudian dihitung persentasenya dan diinterpretasikan sesuai dengan klasifikasi menurut Koentjaraningrat (Monariska, 2017) yang disajikan pada Tabel 2.

Tabel 2. Klasifikasi Interpretasi Perhitungan Persentase

\begin{tabular}{|c|c|}
\hline Besar Persentase & Interpretasi \\
\hline $0 \%$ & Tidak ada \\
\hline $1 \%-25 \%$ & Sebagian kecil \\
\hline $26 \%-49 \%$ & Hampir setengahnya \\
\hline $50 \%$ & Setengahnya \\
\hline $51 \%-75 \%$ & Sebagian besar \\
\hline $76 \%-99 \%$ & Pada umumnya \\
\hline $100 \%$ & Seluruhnya \\
\hline
\end{tabular}

Skala sikap siswa terhadap suatu pernyataan dalam angket, diukur menggunakan skala ukur berdasarkan Skala Likert (Sukardi, 2007: 146) yaitu terdiri atas kategori Sangat Setuju (SS), Setuju (S), Tidak Setuju (TS), dan Sangat Tidak Setuju (STS). Hasil angket tersebut selanjutnya dianalisis dan diinterpretasikan kedalam kategori persentase menurut Koentjaraningrat, seperti yang tertera pada Tabel 2. Hasil akhir itulah yang nantinya akan disimpulkan untuk dideskripsikan.

Wawancara dengan guru mata pelajaran dilakukan sebagai langkah awal (observasi) untuk mengetahui permasalahan apa yang terjadi di sekolah yang akan di teliti. Data yang diperoleh dalam wawacara berbentuk dialog yang disusun dan diringkas untuk dijadikan sumber data yang dibutuhkan dalam penelitian.

\section{Hasil Penelitian dan Pembahasan}

Hasil analisis penelitian yang telah dilaksanakan oleh peneliti sebanyak dua siklus di kelas XI MIA 1 SMA Pasundan 1 Cianjur, dengan menerapkan model pembelajaran kooperatif tipe Student Teams Achievement Division (STAD) pada pembelajaran matematika dalam upaya meningkatkan pemahaman konsep siswa akan dijelaskan sebagai berikut: 
A. Analisis Hasil Penelitian

Analisis Pemahaman Konsep Matematika Siswa Setiap Siklus

Berdasarkan hasil analisis pemahaman konsep matematika siswa setiap siklusnya tampak bahwa pemahaman konsep matematika siswa mengalami peningkatan dari siklus I ke siklus II. Pada siklus I sebanyak 49\% siswa berada pada tingkat pemahaman paham seluruhnya, 29\% paham sebagian dan $22 \%$ miskonsepsi sebagian. Sedangkan pada siklus II, jumlah siswa yang berada pada tingkat pemahaman paham seluruhnya meningkat menjadi $73 \%$, jumlah siswa pada tingkat pemahaman paham sebagian menurun menjadi $11 \%$, dan jumlah siswa pada tingkat pemahaman miskonsepsi sebagian juga menurun menjadi $16 \%$.

Hal ini memberikan kesimpulan pembelajaran matematika menggunakan model pembelajaran kooperatif tipe Student Teams Achievement Division (STAD) dapat meningkatkan pemahaman konsep matematika siswa.

\section{Analisis Ketuntasan Belajar Siswa dan Daya Serap Klasikal (DSK)}

Berdasarkan analisis hasil tes siswa menunjukkan peningkatan hasil ketuntasan belajar siswa dan Daya Serap Klasikal (DSK) dari siklus I dan siklus II. Rata-rata nilai dari keseluruhan siswa pada siklus I sebesar 81.71 meningkat pada siklus II menjadi 89.29. Nilai tertinggi yang diperoleh siswa pada siklus I dan siklus II tetap yaitu 100. Nilai terendah yang diperoleh siswa meningkat dari 65 menjadi 70. Siswa yang tuntas meningkat dari 27 menjadi 30 orang siswa, sedangkan siswa yang tidak tuntas menurun dari 8 menjadi 5 orang siswa. DSK pada siklus I sebesar $77.14 \%$ meningkat menjadi $85.71 \%$ pada siklus II. Maka DSK pada kedua siklus mengalami peningkatan sebesar 8.57\%. Ini berarti pada siklus II, kelas ini sudah memenuhi kriteria ketuntasan belajar. Hal ini memberikan kesimpulan bahwa pembelajaran matematika menggunakan model pembelajaran kooperatif tipe Student Teams Achievement Division (STAD) dapat meningkatkan hasil ketuntasan belajar siswa dan Daya Serap Klasikal (DSK).

\section{Analisis Observasi Setiap Siklus}

Dari hasil analisis lembar observasi aktivitas siswa pada setiap siklus dapat disimpulkan bahwa aktivitas siswa dalam pembelajaran matematika dengan menggunakan model pembelajaran kooperatif tipe Student Teams Achievement Division (STAD) dapat terlaksana dengan baik. Hal ini terbukti dengan adanya peningkatan persentase skor keseluruhan aktivitas siswa dari siklus I dan siklus II. 


\section{Analisis Jurnal Setiap Siklus}

Padahasil analisis jurnal siswa, terlihat bahwa pada siklus I dan siklus II persentase sikap positif siswa sama besar yaitu $97.14 \%$. Jadi tampak jelas sejak siklus I sampai siklus II, pada umumnya siswa bersikap positif dan dapat menerima dengan sangat baik terhadap pembelajaran matematika dengan menggunakan model pembelajaran kooperatif tipe Student Teams Achievement Division (STAD).

Analisis Skala Sikap

Tabel 3. Persentase Sikap Siswa Secara Keseluruhan

\begin{tabular}{|c|l|c|c|}
\hline \multirow{2}{*}{ No. } & \multicolumn{1}{|c|}{ Indikator } & \multicolumn{2}{|c|}{ Sikap Siswa } \\
\cline { 3 - 4 } & & Positif & Negatif \\
\hline 1 & Pembelajaran Matematika & $82.86 \%$ & $17.14 \%$ \\
\hline 2 & $\begin{array}{l}\text { Model Pembelajaran Kooperatif } \\
\text { Tipe Student Teams Achievement } \\
\text { Division (STAD) }\end{array}$ & $93.71 \%$ & $6.29 \%$ \\
\hline 3 & Soal yang diberikan & $73.14 \%$ & $26.86 \%$ \\
\hline \multicolumn{2}{|c|}{ Rata-rata Sikap Siswa Keseluruhan } & $85.86 \%$ & $14.14 \%$ \\
\hline
\end{tabular}

Dari Tabel 3 terlihat bahwa pada umumnya siswa bersikap positif terhadap pembelajaran matematika, pada umumnya siswa bersikap positif terhadap model pembelajaran kooperatif tipe Student Teams Achievement Division (STAD), dan sebagian besar siswa bersikap positif terhadap soal-soal yang diberikan oleh guru. Berdasarkan analisis skala sikap yang ditinjau dari setiap indikator, maka dapat disimpulkan bahwa sikap siswa bersifat positif.

Dilihat dari hasil analisis jurnal dan skala sikap di atas, dapat disimpulkan bahwa pada umumnya siswa bersikap positif terhadap pembelajaran matematika dengan menggunakan model pembelajaran kooperatif tipe Student Teams Achievement Division (STAD). Hal ini terbukti dari persentase sikap positif siswa yang selalu jauh lebih besar dibandingkan dengan persentase sikap negatif, baik pada analisis jurnal maupun analisis skala sikap. Ini berarti bahwa siswa dapat menerima pembelajaran matematika dengan menggunakan model pembelajaran kooperatif tipe Student Teams Achievement Division (STAD) dalam upaya meningkatkan pemahaman konsep siswa. 


\section{B. Pembahasan Dari Analisis Hasil Penelitian}

\section{Peningkatan Pemahaman Konsep Matematika}

Berdasarkan hasil analisis data tes siklus, terjadi peningkatan rata-rata nilai keseluruhan siswa dan ketuntasan belajar siswa dari siklus I ke siklus II, sehingga menunjukkan bahwa pembelajaran matematika dengan menggunakan model pembelajaran kooperatif tipe Student Teams Achievement Division (STAD) dapat meningkatkan pemahaman konsep siswa. Hal ini terjadi karena proses pembelajaran yang dilakukan mengarahkan siswa untuk dapat memahami konsep atau prinsip dari suatu materi sehingga siswa akan terbiasa menyelesaikan soal dengan tepat sesuai dengan prosedur dan mampu mengaplikasikan konsep dalam soal pemecahan masalah yang berkaitan dengan kehidupan sehari-hari (Septian \& Rizkiandi, 2017).

Jika dilihat dari kriteria ketuntasan belajar secara klasikal maka hasil tes siklus I dan II menunjukkan pemahaman konsep matematika siswa meningkat setelah mengikuti pembelajaran dengan model pembelajaran kooperatif tipe Student Teams Achievement Division (STAD). Pada akhir pelaksanaan siklus I, dari jumlah siswa sebanyak 35 orang hanya 27 atau $77.14 \%$ yang mencapai ketuntasan belajar sehingga kelas tersebut dinyatakan belum mencapai ketuntasan belajar secara klasikal. Tetapi pada siklus II, kelas tersebut dinyatakan sudah mencapai ketuntasan belajar secara klasikal karena banyaknya siswa yang tuntas sudah $\geq 85 \%$ dari jumlah seluruh siswa yaitu $85.71 \%$ atau sama dengan 30 orang siswa.

Peningkatan pemahaman konsep matematika yang terjadi di kelas tersebut sangat dipengaruhi oleh model pembelajaran yang diterapkan yaitu model pembelajaran kooperatif tipe Student Teams Achievement Division (STAD). Karena di dalam model pembelajaran STAD ini terdapat kegiatan penghargaan kelompok, dimana kelompok yang berhasil mendapatkan skor tertinggi akan mendapatkan hadiah. Kegiatan inilah yang membuat siswa lebih termotivasi untuk memperbaiki kualitas belajar mereka di siklus berikutnya. Selain itu, hal-hal yang ada dalam pembelajaran kooperatif tipe Student Teams Achievement Division (STAD) yang berpengaruh terhadap peningkatan pemahaman konsep matematika siswa adalah belajar kelompok. Dengan adanya belajar kelompok diharapkan siswa dapat lebih memahami materi dengan penjelasan temannya sendiri, apalagi kelompok tersebut dibentuk secara heterogen dimana dalam setiap kelompoknya terdapat anggota dengan kemampuan belajar yang beragam mulai dari siswa dengan kemampuan tinggi, sedang, sampai rendah. Sehingga siswa dengan kemampuan belajar 
yang lebih tinggi bertanggung jawab untuk membantu teman satu kelompoknya untuk dapat lebih memahami materi. Presentasi di depan kelas juga berperan dalam meningkatkan pemahaman konsep matematika siswa. Hal ini dikarenakan, ketika siswa mempresentasikan hasil belajar kelompoknya didepan kelas dengan bahasanya sendiri, guru dapat mengetahui sejauh mana pemahaman siswa terhadap materi yang dipelajari. Dan apabila terjadi kesalahpahaman terhadap konsep, maka guru dapat segera meluruskan kesalahan tersebut.

\section{Aktivitas Siswa}

Berdasarkan hasil penelitian, dilihat dari hasil lembar observasi yang dibantu oleh observer pada tiap siklusnya menunjukkan bahwa hasil persentase aktivitas siswa mengalami peningkatan. Pada siklus I aktivitas siswa berada pada kategori tinggi, atau dapat disimpulkan bahwa aktivitas siswa dalam pembelajaran matematika menggunakan model pembelajaran kooperatif tipe Student Teams Achievement Division (STAD) sudah terlaksana dengan baik, pada siklus II aktivitas siswa berada pada kategori sangat tinggi atau dapat disimpulkan bahwa aktivitas siswa dalam pembelajaran matematika menggunakan model pembelajaran kooperatif tipe Student Teams Achievement Division (STAD) sudah terlaksana dengan sangat baik. Artinya dalam pembelajaran matematika dengan menggunakan model pembelajaran kooperatif tipe Student Teams Achievement Division (STAD) dapat membuat siswa lebih aktif dalam belajar, memiliki motivasi yang tinggi, dan berani untuk mempresentasikan hasil kerjanya di depan kelas. Sedangkan dalam kegiatan belajar kelompok, siswa menjadi lebih menyadari arti kerja sama yang baik, mau berbagi ilmu dengan teman, dan dapat saling membantu satu sama lain.

Pada siklus I, aktivitas siswa berada pada kategori tinggi. Sedikit kekurangan yang terdapat pada siklus I diantaranya siswa kurang aktif berdiskusi dalam kelompok masingmasing, hal ini disebabkan ada beberapa siswa yang masih mengandalkan temannya untuk mengerjakan soal yang terdapat pada LKS, ada juga siswa yang sibuk mengobrol dengan temannya, ataupun secara diam-diam bermain dengan telepon genggamnya. Selain itu, dilihat dari hasil observasi masih ada beberapa siswa yang kurang termotivasi untuk belajar matematika karena mereka masih menganggap matematika adalah pelajaran yang sulit dan kurang menyenangkan. Kemudian pada siklus I juga terdapat kekurangan siswa tidak mencatat kesimpulan materi diakhir pembelajaran, karena kurangnya manajemen waktu 
yang dilakukan oleh peneliti. Namun peneliti merencanakan perbaikan yang harus dilakukan pada tindakan siklus berikutnya.

Dilihat dari hasil observasi pada siklus I yang memberikan hasil bahwa siswa kurang aktif dalam berdikusi ketika kegiatan belajar kelompok, siswa kurang termotivasi dan kurangnya manajemen waktu yang dilakukan oleh peneliti, maka peneliti menerapkan perbaikan-perbaikan yang telah direncanakan sebelumnya. Diantaranya peneliti lebih tegas dalam mengkondisikan siswa, peneliti bersikap lebih menyenangkan dalam menyampaikan pelajaran sehingga siswa akan merasa nyaman ketika belajar matematika, dan peneliti lebih mempersiapkan segalanya dengan matang dan dapat mengatur waktu sesuai dengan rencana pembelajaran.

Sehingga pada siklus II, aktivitas siswa dalam pembelajaran dengan model pembelajaran kooperatif tipe Student Teams Achievement Division (STAD) menunjukkan peningkatan. Pada siklus II ini secara keseluruhan siswa lebih aktif dalam belajar kelompok meskipun masih ada beberapa yang mengobrol, siswa memiliki motivasi yang tinggi dalam belajar, dan manajemen waktu yang dilakukan peneliti menjadi lebih baik sehingga guru bersama-sama dengan siswa dapat membuat kesimpulan materi diakhir pembelajaran. Hal ini membuat peneliti merasa berhasil melakukan penelitian di kelas ini dengan menggunakan model pembelajaran kooperatif tipe Student Teams Achievement Division (STAD).

\section{Sikap Siswa}

Sikap siswa dalam pembelajaran matematika terlihat dari hasil pengolahan jurnal dan skala sikap. Dari hasil jurnal pada siklus I dan siklus II pada umunya siswa bersikap positif terhadap pembelajaran matematika dengan menggunakan model pembelajaran kooperatif tipe Student Teams Achievement Division (STAD) dan bahan ajar atau soal-soal yang diberikan sebagai pemicu pemahaman konsep matematika siswa. Hal ini berarti bahwa siswa dapat menerima dengan baik pembelajaran dengan menggunakan model pembelajaran kooperatif tipe Student Teams Achievement Division (STAD) pada pokok bahasan statistika. Siswa merasa tertarik belajar matematika dengan menggunakan model pembelajaran kooperatif tipe Student Teams Achievement Division (STAD), sehingga lebih mudah memahami materi yang sedang dipelajari karena pembelajarannya dilakukan secara berkelompok dan ditambahkan dengan adanya kuis serta penghargaan kelompok. Siswa merasa tertantang dan menyadari pentingnya kerjasama untuk menjadi yang terbaik. 
Kemudian dilihat dari hasil analisis skala sikap, terlihat bahwa pada umumnya siswa bersikap positif terhadap pembelajaran matematika, pada umumnya siswa bersikap positif terhadap model pembelajaran kooperatif tipe Student Teams Achievement Division (STAD), dan sebagian besar siswa bersikap positif terhadap soal-soal yang diberikan oleh guru. Berdasarkan analisis skala sikap yang ditinjau dari setiap indikator, maka dapat disimpulkan bahwa sikap siswa bersifat positif. Hal ini diduga karena kegiatan yang disajikan oleh peneliti dapat diterima dengann baik oleh siswa, sehingga dapat disimpulkan bahwa siswa bersikap positif terhadap pembelajaran matematika dengan menggunakan model pembelajaran kooperatif tipe Student Teams Achievement Division (STAD).

\section{Simpulan}

Berdasarkan hasil penelitian yang telah dilaksanakan, maka dapat disimpulkan sebagai berikut: Penerapan model pembelajaran kooperatif tipe Student Teams Achievement Division (STAD) dapat meningkatkan pemahaman konsep matematika siswa, aktivitas siswa sangat baik terhadap pembelajaran matematika dengan menggunakan model pembelajaran kooperatif tipe Student Teams Achievement Division (STAD) dan sikap siswa positif terhadap pembelajaran matematika dengan menggunakan model pembelajaran kooperatif tipe Student Teams Achievement Division (STAD).

\section{Referensi}

Anggriani, A., \& Septian, A. (2019). Peningkatan Kemampuan Komunikasi Matematis dan Kebiasaan Berpikir Siswa Melalui Model Pembelajaran IMPROVE. IndoMath: $\begin{array}{llll}\text { Indonesia } \quad \text { Mathematics } & & \end{array}$ https://doi.org/10.30738/indomath.v2i2.4550

Depdiknas. (2003). Undang-Undang RI No 20 Tahun 2003. In Undang-Undang Republik Indonesia Nomor 20 Tahun 2003 Tentang Sistem Pendidikan Nasional Dengan Rahmat Tuhan Yang Maha Esa Presiden Republik Indonesia.

Depdiknas. Peraturan pemerintah Republik Indonesia Nomor 19 tahun 2005 tentang standar nasional pendidikan., Peraturan pemerintah Republik Indonesia (2005).

Dewiatmini, P. (2010). Upaya Meningkatkan Pemahaman Konsep Matematika Pada Pokok Bahasan Himpunan Siswa Kelas VII A Smp Negeri 14 Yogyakarta Dengan Penerapan Model Pembelajaran Kooperatif Tipe Student Teams Achievement Divisions (STAD). Skripsi.

Inayah, S., Septian, A., \& Suwarman, R. F. (2020). Student Procedural Fluency in Numerical Method Subjects. Desimal: Jurnal Matematika, 3(1), 53-64. https://doi.org/10.24042/djm.v3i1.5316

Jusniani, N. (2018). Analisis Kesalahan Jawababn Siswa Pada Kemampuan Pemahaman Matematis Melalui Pembelajaran Kontekstual. Prisma, VII(1), 82-90. 
Maskur, R., Sumarno, Rahmawati, Y., Pradana, K., Syazali, M., Septian, A., \& Palupi, E. K. (2020). The effectiveness of problem based learning and aptitude treatment interaction in improving mathematical creative thinking skills on curriculum 2013. European Journal of Educational Research, 9(1), 375-383. https://doi.org/10.12973/eu-jer.9.1.375

Monariska, E. (2017). Penerapan Metode Mind Mapping untuk Meningkatkan Kemampuan Pemahaman Konsep Matematis Mahasiswa pada Mata Kuliah Kalkulus I. PRISMA, 6(1), 17-31. https://doi.org/10.35194/jp.v6i1.25

NCTM. (2014). Executive summary principles and standards for school mathematics. National Council of Teachers of Mathematics, 1-6. Retrieved from https://www.worldcat.org/title/principles-and-standards-for-schoolmathematics/oclc/805048548\%0Ahttp://ezproxy.library.wisc.edu/login?url=http://sear ch.ebscohost.com/login.aspx ?direct=true $\& d b=$ eric $\& A N=E D 429844 \&$ site $=$ ehost live\%0Ahttp://www.nctm.org/uploaded

Yanuar, Sukmawati, K. I., \& Arifin, S. (2019). Penerapan model Student Teams Achievement Division terhadap kemampuan pemahaman konsep matematika siswa kelas VIII. Union.

Zyngier, D., Zullig, K. J., Collins, R., Ghani, N., Hunter, A. A., Patton, J. M.. (2013). PISA 2012 results : ready to learn. Students' engagement, drive and self-beliefs (volume III). School Effectiveness and School Improvement, 24(2), 520 pages. https://doi.org/10.1080/09243453.2012.680892 